\title{
PHYTOCHEMICAL SCREENING AND TOXICITY OF Crambe abyssinica Hochst EXTRACTS ON Solanum lycopersicum L., Euphorbia heterophylla L., Bidens pilosa L. AND Glycine max (L.) Merril
}

\author{
SCREENING FITOQUÍMICO E TOXICIDADE DE EXTRATOS DE Crambe \\ abyssinica Hochst SOBRE Solanum lycopersicum $L$., Euphorbia heterophylla $L$., \\ Bidens pilosa $L$. E Glycine max (L.) Merril
}

\section{Ariane SPIASSI ${ }^{*}$; Andréa Maria Teixeira FORTES²; Luciana Pagliosa Carvalho GUEDES ${ }^{3}$; Gislaine Piccolo de LIMA ${ }^{1}$; Rennan Oliveira MEIRA ${ }^{4}$; Raquel VALMORBIDA ${ }^{4}$; Lorena Camargo de MENDONÇA ${ }^{5}$}

1. Bióloga, Doutora em Engenharia Agrícola, Universidade Estadual do Oeste do Paraná - UNIOESTE, campus Cascavel, PR, Brasil. arispiassi@ hotmail.com*; 2. Universidade Estadual do Oeste do Paraná, UNIOESTE, campus Cascavel, PR, Brasil; 3. Programa de PósGraduação em Engenharia Agrícola, PGEAGRI- UNIOESTE, campus Cascavel, PR, Brasil; 4. Mestre em Conservação e Manejo de Recursos Naturais - UNIOESTE, campus Cascavel, PR, Brasil; 5. Mestre em Engenharia Agrícola - UNIOESTE, campus Cascavel, PR, Brasil.

\begin{abstract}
This study aimed to identify the main groups of secondary compounds from Crambe abyssinica and evaluate the bioactivity of the hexane, ethyl acetate and methanol extracts on the seed germination and seedling development of tomato, wild poinsettia, hairy beggartick and soybean. The phytochemical screening considered the presence or absence of total saponins, triterpenoids, flavonoids, coumarins, tannins, phenols and alkaloids. In the seeds it was evaluated: germination percentage, germination velocity index, average germination time, index of allelopathic effects, shoot and root length and seedlings dry matter. In the phytochemical screening it was observed that each solvent extracted different compounds. Flavonoids were found only in the ethyl acetate extract and saponin only in the methanol extract. A high allelopathic effect of hexane, ethyl acetate and methanolic extracts of crambe on the bio-indicator species tomato was observed. The hexane and ethyl acetate extracts also showed inhibitory effect on the weed hairy beggartick and did not present negative effects on soybean. There is the possibility of isolating the bio-active compounds of crambe and use them as a bio-herbicide to the alternative control of the weed hairy beggartick.
\end{abstract}

KEYWORDS: Bioherbicide. Control hairy beggartick. Crambe extracts.

\section{INTRODUCTION}

Plants have the ability to produce chemical substances which can contribute to their survival besides developing defense mechanisms in their environment. These substances are bioactive metabolites, called allelochemicals, they derive from the secondary metabolism. Some allelochemicals are very specific and restricted to certain species or group of related species and, they can be divided into three main groups: terpenes, phenolic compounds and nitrogen compounds (TAIZ; ZEIGER, 2013).

These allelopathic substances can cause positive and negative effects on other plants. Such effects include delay or inhibition on seeds germination, paralyzed growth, damages to the root system, chlorosis, withering and plant death (EINHELLIG, 1986; CORREIA et al., 2005; TAIZ; ZEIGER, 2013). Usually, these substances are water soluble, highlighting the saponins, tannins, alkaloids, terpenoids and flavonoids, which are released directly into the environment through leaching, root exudates, volatilization and plant residue decomposition (ALVES et al., 2004).

The recognition of the secondary metabolites biological properties has fuelled the search for new drugs, antibiotics, insecticides and herbicides (MACEDO JUNIOR, 2007). The starting point for obtaining these alternative compounds is the preliminary approach, since besides facilitating the material choice to be studied, it allows the possibility to adapt to the isolation and fractionation technique, and characterization of pure substances, according to the nature of the constituents previously detected, easing the subsequent work of the more interesting constituents (MATOS, 2009).

Another aspect to be mentioned is that plants from the Family Brassicaceae produce secondary metabolites which can be agriculturally relevant, because they can be used in the alternative control of weeds. According to Weih et al. (2008), the possibility of using allelopathic activity as an alternative to the chemical control in order to 
suppress weeds should be acknowledged. Thus, Jabran et al. (2015) highlight that allelopathy can be an important tool to fight the challenges around environmental pollution, and the development of herbicide resistance.

In a study by Onyilagha et al. (2003), $C$. abyssinica presented flavones (quercetin, luteolin and apigenin). As reported by Borges et al. (2012), in the forage radish (Raphanus sativus L.), which belongs to the same family as the crambe (Crambe abyssinica), flavonoids and triterpenes were already found. The crambe is an oleaginous species, from the family Brassicaceae, cultivated for the purpose of oil extraction to produce biodiesel. It presents between 1.000 and $1.500 \mathrm{~kg} \mathrm{ha}^{-1}$ of productivity and 25 liters of oil yield for each $100 \mathrm{~kg}$ of grains, which presents approximately $38 \%$ of oil content (FALASCA et al., 2010; PITOL; BROCH; ROSCOE, 2010). It is a good alternative as an Autumn/Winter culture, producing soil cover and establishing a direct planting system in the South and Central-West of Brazil, since it can be characterized as resistant to water deficit, low temperatures and it also enables crop rotation and the succession of other cultures, highlighting the soybean culture in the South and Central regions of Brazil (PITOL; BROCH; ROSCOE, 2010; CONCENÇO et al., 2012).

There are several studies about the importance of allelopathy for the management of weeds. Some cultivated species such as cereal rye, sorghum, rice, sunflower, colza and wheat were documented as crops with important allelopathic potential to eliminate weeds in field conditions. Besides, the use of plants from crop rotations can suppress weeds in the cultures (JABRAN et al., 2015).
Considering the hypothesis that plants extracts used in crop rotation system can inhibit the germination and growth of weeds, due the presence of allelopathic compounds, when evaluated in laboratory conditions, the aim of this study was to identify the main groups of secondary compounds present on crambe (Crambe abysinica) and evaluate the effect of hexane, ethyl acetate and methanolic extracts on seeds germination and seedlings growth of the bioindicator tomato (Solanum lycopersicum), the weeds wild poinsettia (Euphorbia heterophylla) and hairy beggartick (Bidens pilosa) and the cultivated plant soybean (Glycine max).

\section{MATERIAL AND METHODS}

\section{Cultivation and plant material processing}

The crambe (FMS brilhante cultivar) was cultivated from May to July 2014, in an agriculture area of the municipality of Cascavel - PR, $700 \mathrm{~m}$ height, between latitudes 24'56'25.39' S; 24 $56^{\prime} 45.39^{\prime \prime} \mathrm{S}$ and longitudes 53'30'9.89" O; $53^{\circ} 31^{\prime} 17.01^{\prime \prime} \mathrm{O}$. The climate is considered Cfa (subtropical climate), according to Koeppen (1948), with an average annual rainfall superior to 1800 $\mathrm{mm}$, without a well-defined dry season and with the possibility of frosts during winter. The soil is classified as Eutroferric Red Latosol (EMBRAPA, 2013). The daily rainfall and average daily temperature $\left({ }^{\circ} \mathrm{C}\right)$ of planting until flowering are presented on Figure 1. The weather conditions were favorable for the proper crop development according to Pitol, Broch end Roscoe (2010) recommendations. The average temperature during the cultivation period was $22^{\circ} \mathrm{C}$, since neither negative temperatures nor critic periods of water deficit happened.

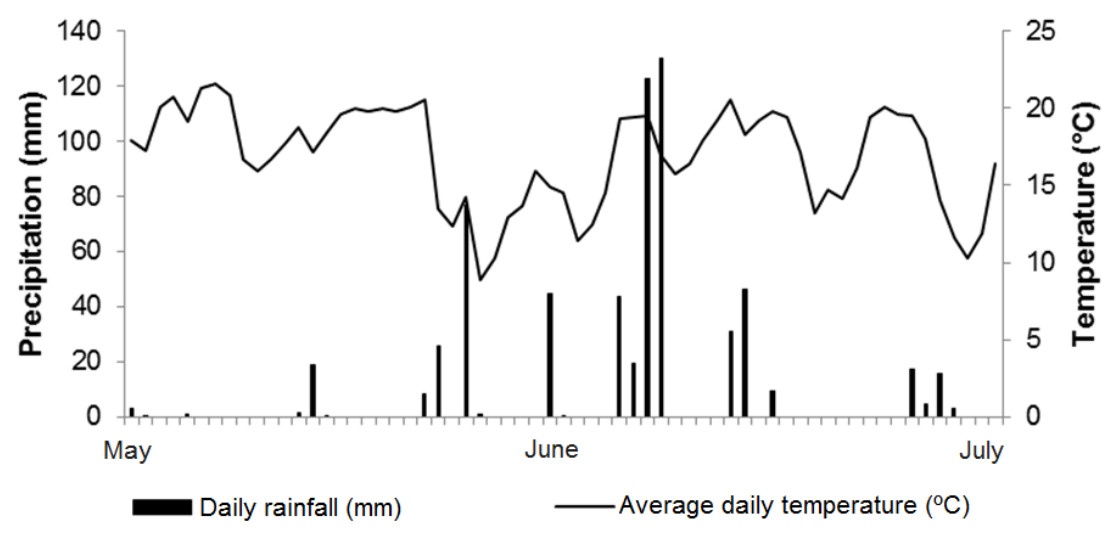

Figure 1. Daily rainfall $(\mathrm{mm})$ and average daily temperature $\left({ }^{\circ} \mathrm{C}\right)$ during Crambe abyssinica cultivation, from May to July 2014. Data obtained from the SIMEPAR meteorological station. 
The crambe shoot was collected at the flowering phase and it was dried in a forced ventilation oven at $40^{\circ} \mathrm{C}$ for $72 \mathrm{~h}$. After this, the dry material was milled on Willey Cutting Mill, STAR FT-50 model, using a sieve mesh of $30 \mathrm{~mm}$, and it was stored in plastic bags away from light and humidity and kept under environment temperature. The biomass was used for the exhaustive extraction in order to obtain the extracts for the posterior phytochemical analysis and also in the germination and seedlings growth bioassays.

\section{Exhaustive extraction and extracts obtainment}

The dry and milled crambe material was submitted to successive extraction with solvents of growing polarity in the Plant Physiology laboratory at Western Parana State University - UNIOESTE. The process began with hexane, going to ethyl acetate and ending with methanol (two extractions for each solvent), which resulted, respectively, in the hexane, ethyl acetate and methanolic extracts. Each solution was filtered and concentrated under reduced pressure, using the rotary evaporator Tecnal, model TE 211, obtaining then the respectively crude extracts. The extraction was performed during six days, according to Souza Filho et al. (2005) and Ripardo Filho et al. (2012).

The amount of plant material, solvents, extract and yield obtained are described on Table 1 . The ethyl acetate provided a greater amount of extract ( $24.56 \mathrm{~g}$ ) and, therefore, a greater yield (1.23 $\%)$.

Table 1. Amount of plant material milled, amount of solvent used, extract obtained and yield for the three extracts of Crambe abysinica.

\begin{tabular}{|c|c|c|c|}
\hline \multicolumn{4}{|c|}{ Solvent } \\
\hline & Hexane & Ethyl acetate & Methanol \\
\hline Amount of crambe milled $(\mathrm{Kg})$ & 2 & 2 & 2 \\
\hline Amount of solvent (L) & 15 & 13 & 13 \\
\hline Extract obtained(g) & 11,19 & 24,52 & 10,95 \\
\hline Yield $(\%)$ & 0,56 & 1,23 & 0,55 \\
\hline
\end{tabular}

\section{Phytochemical screening}

The phytochemical screening or phytochemical research identifies the main groups of substances which compose a plant extract. It is a qualitative test which through staining reagents or precipitation reveals the presence or absence of secondary metabolites in the sample (BESSA et al., 2013).

The research in the hexane, ethyl acetate and methanolic extracts of crambe, obtained in the exhaustive extraction, was performed following Matos (2009) and Paracampo (2011) methodology, for the compounds: saponins, pentacyclic triterpenoids, free steroids, flavonoids (flavones/xanthones), coumarins, tannins, phenols and alkaloids.

\section{Germination bioassay}

The extracts obtained in the exhaustive extraction were submitted to evaluation regarding the ability to inhibit seed germination. The bioassay was developed in sprouting cameras, under controlled conditions of $25{ }^{\circ} \mathrm{C}$ of constant temperature and 12 hours of photoperiod. The weeds seeds were collected in an agricultural area in the municipality of Cascavel - PR, between January and March of 2015. The tomato and soybean seeds were acquired in the local market.
The extracts were used in the $1 \%$ concentration, mass/volume relationship $(\mathrm{g} / \mathrm{mL})$, in all the tested species. Each crude extract (hexane, ethyl acetate and methanolic) was dissolved in their respective solvent, following the adapted methodology of Souza Filho et al. (2010).

For the tomato, wild poinsettia and hairy beggartick, because they are considered small, the methodology of Souza Filho et al. (2010) and Ripardo Filho (2012) was used. In petri dishes, 3 $\mathrm{mL}$ of extract were applied on two sheets of qualitative filter paper. The complete evaporation of the solvent lasted 24 hours and only then the filter paper was soaked with distilled water $(3 \mathrm{~mL})$. For the soybean seeds paper rolls were used as substrate to germination, soaked in the proportion of two times and half the paper weight, following the methodology of BRASIL (2009).

25 seeds of each species were sown: tomato (bioindicator), wild poinsettia and hairy beggartick (weeds) and soybean (cultivated) were sowed. For all the species a negative control (containing only water) and a positive control (containing the commercial herbicide atrazine) were used. Every treatment and control had four repetitions.

The positive control was performed with the commercial herbicide atrazine $500 \mathrm{~g} \mathrm{~L}^{-1}(50 \% \mathrm{~m} / \mathrm{v})$. The solution was prepared according to the recommendations of use (4 kg.i.a.ha $\left.{ }^{-1}\right)$, considering 
the area of the petri dishes used. According to the Ministry of Agriculture, Livestock, and Supply this herbicide is presented in the form of concentrated suspension, efficient in the control of most of the annual weeds, for the pre-emergence control application as well as for the post-emergence.

The germination was monitored during eight days. For all the species, seeds were only considered germinated when they presented primary root with at least $2.00 \mathrm{~mm}$ (JUNTILA, 1976, DURAM; TORTOSA, 1985). The counting of germinated seeds was performed from the first day after the first germinated seed, until the seedlings number was stabilized, following the methodology described by Nakagawa (1999).

The germination percentage (BRASIL, 2009), germination velocity index (GVI) (MAGUIRE, 1962) and average germination time (AGT) were calculated (EDMOND; DRAPALLA, 1958; LABOURIAU, 1983).

From the germination data, the allelopathic effect index $(A I)$ was also calculated according to Gao et al. (2009) by the following equation:

$\left\{\begin{array}{ll}R I=1-C / T, & \text { se } T \geq C \\ R I=T / C-1, & \text { se } T<C\end{array}\right.$.

(Equation 01)

In which: $\mathrm{C}=$ control germination velocity and $\mathrm{T}=$ treatment germination velocity. $A I$ is a qualitative index, given that negative values indicate inhibitory activity while positive values indicate stimulant activity. For this the germination velocity was calculated according to Gao et al. (2009):

Germination velocity $(\%)=$

$100 \sum_{l=1}^{Q}\left(G t_{i} / G c_{i}\right)$ (Equation 02)

being: $\mathrm{Gt}=$ number of daily seeds germinated of treatment $\mathrm{Gc}=$ number of daily seeds germinated of control $\mathrm{D}=$ number of corresponding days.

\section{Bioassay of seedlings growth}

The bioassay of seedlings growth was performed in the same conditions as the germination test. However, 10 pre-germinated seedlings of each species were used. Seeds of tomato, wild poinsettia and hairy beggartick were placed in petri dishes covered with two sheets of qualitative filter paper soaked with $3 \mathrm{~mL}$ of distilled water. After two days they were transferred to petri dishes containing each treatment (distilled water (negative control); commercial herbicide (positive control); hexane extract $1 \%$; ethyl acetate extract $1 \%$ and methanolic extract $1 \%$ ), using the methodology proposed by Souza Filho et al. (2010) and Ripardo Filho (2012). For the cultivated species (soybean) paper rolls were used as substrate (BRASIL, 2009).
After eight days, root and shoot length (cm) were evaluated. Next, the plants were taken to the oven at $65{ }^{\circ} \mathrm{C}$ until reaching a constant weight, for the dry matter $(\mathrm{g})$ determination.

\section{Experimental design and data analysis}

The experimental design was completely randomized (CRD) with five treatments, which were composed by: distilled water (negative control); commercial herbicide (positive control); hexane extract $1 \%$; ethyl acetate extract $1 \%$ and methanolic extract $1 \%$. These were applied on seeds of tomato (bioindicator), wild poinsettia and hairy beggartick (weeds) and soybean (cultivated plant). Each treatment had four repetitions.

For each variable, descriptive analysis and the evaluation of the suppositions associated to the statistical model were performed, considering the normality test (Shapiro-Wilk test), and the variance homoscedasticity (Bartlett's test). In addition, the analysis of variance (ANOVA) was made and the treatments were compared with every control by the Dunnett test.

For the variables which the data did not meet the statistical model suppositions (absence of normality and/or variances heterogeneity) the Kruskal-Wallis test (non-parametric alternative for the ANOVA as a factor) was used. These treatments were compared with every control through the Wilcoxon test (test similar to Dunnett).

The statistical analyses were performed through the free software $\mathrm{R}$ 3.2.1 (R DEVELOPMENT CORE TEAM, 2015). In all the hypothesis tests performed, $5 \%$ of significance was considered.

\section{RESULTS AND DISCUSSION}

\section{Phytochemical Screening}

The chemical prospection or phytochemical screening indicated the presence of saponin, pentacyclic triterpenoids, free steroids, flavonoids and tannins. Coumarins, phenols and alkaloids were not found (Table 2). In forage raddish (Raphanus sativus L.), belonging to the same family as the crambe (Brassicaceae), triterpenes and flavonoids, as reported by Borges et al. (2012).

According to Matos (2009), the preliminary prospection of natural products has as immediate goals clarify and record the resulting constituents from the secondary metabolism of the plants, and also discover substances of economic interest, compounds which can be precursors for the synthesis of substances of interest. 
Table 2. Phytochemical screening of crambe extracts obtained through exhaustive and successive extraction. Cascavel - PR, 2015.

\begin{tabular}{llll}
\hline \multirow{2}{*}{ Compound } & Solvent & & Methanol \\
\cline { 2 - 4 } & Hexane & Ethyl acetate & + \\
\hline Saponin & -- & -- & + \\
Pentacyclic triterpenoids & + & -- & + \\
Free steroids & + & + & -- \\
Flavonoids (flavones/xanthones) & -- & + & -- \\
Coumarins & -- & -- & + \\
Tannins & -- & + & -- \\
Phenols & -- & -- & -- \\
Alkaloids & -- & -- & \\
\hline
\end{tabular}

The absence of phenolic compounds can be explained due the fact that the crambe is cultivated in the winter, and, since short days provide less insolation this may not induce the plant to produce such secondary compound. Rice (1984) noticed that longer days enhance the concentration of phenolic acids and terpenes in several plant species.

In the hexane extract, the presence of pentacyclic triterpenoids and free steroids was observed. In the ethyl acetate extract, however, the presence of free steroids, tannins and flavonoids (flavones/xanthones) was noticed. In the methanolic extract it was verified the greater number of compounds: saponin, pentacyclic triterpenoids, free steroids and tannins (Table 2).

The terpenes, terpenoids or isoprenoids constitute the bigger class of secondary metabolites. Most of them has low water solubility and are usually volatile. Others present plant growth or development functions, such as the gibberellins, an important group of phytohormones, they are diterpenes (DUKE et al., 2000; TAIZ; ZEIGER, 2013).

The steroids are derived from triterpenes, essential compounds of the cell membranes (TAIZ; ZEIGER, 2013; FAGAN et al., 2015). One of the most important functions of the free steroids is, probably, the contribution to the membrane stability. Besides, some of them have allelochemical activity (SALISBURY; ROSS, 2012).

Saponins are also triterpenes, so-called because of their detergent and emulsifier properties. It is believed that their toxicity is due the ability to form compounds such as steroids (TAIZ; ZEIGER, 2013). Grisi et al. (2011) have associated the inhibitory effects on the germination and growth of vegetables and weeds with the presence of allelopathic compounds, especially saponins. These, can alter the cytological characteristics, membrane properties, germination, respiration and enzyme activity of plants.
Tannins occur in a wide variety of plants. This compound is considered as a defense mechanism of plants against pathogenic fungus, bacteria, virus (TAKECHI et al., 1985) and against the attack of herbivorous insects (KATOH et al., 1989; TEMMINK et al., 1989). Harris and Burns (1970) reported that condensed tannins in the grains of certain sorghum hybrids inhibit the germination of sorghum in the ear and the attack of fungus. According to Cannas (2015) tannins are found mainly in the plants vacuole, where they do not interfere in their development, since, only after an injury or death of the plant they act and have an efficient metabolism.

Flavonoids constitute the bigger class of plant phenols. They are classified, primarily, by the degree of oxidation of the three carbons chain. They present several functions, among them plant protection against the incidence of ultraviolet and visible light, fungus, insects, virus and bacteria; antioxidant; enzyme inhibitors, allelopathic agents, among others (ZUANAZZI; MONTANHA, 2003; RAVEN et al., 2014). They alter the mitochondria and chloroplast membrane permeability (MORELAND; NOVITZKY, 1987). This class can have a varied and strong biological activity, which could be isolated for be used as herbicide (SOUZA FILHO; ALVES, 2002).

Even though we have not found coumarins in this experiment, they occur in all plant parts and are widely distributed in the plant kingdom. Several of them are involved in allelopathic activities and are pointed as inhibitors of plant growth, seed germination and nitrifying bacteria (RICE; PANCHOLY, 1973, EVENARI, 1984).

Although a great number of the plants secondary products have already been identified, only 400 thousand of them present allelopathic activities. Some of these products or their analogous could provide new and important sources of chemical substances for the figure use on agriculture 
(SOUZA FILHO; ALVES, 2002; JABRAN et al., 2015).

\section{Extracts effects on seed germination}

The results referring to the germination of $S$. lycopersicum, E. heterophylla, B. pilosa and G. max submitted to the $C$. abyssinica extracts, distilled water (negative control) and herbicide (positive control) are presented on Table 3.

The seeds of $S$. lycopersicum presented reduction on the germination percentage $(\mathrm{G} \%)$ and GVI, when submitted to the hexane, ethyl acetate and methanolic extracts and compared to the negative control (water). When comparing to the positive control (herbicide) it also did not show any significant statistic difference, with $5 \%$ of significance, in the treatments to the analyzed variables, however, the methanolic extract increased the germination percentage and GVI. Thus, the tested extracts promoted effects on the germination of $S$. lycopersicum seeds, highlighting the hexane and ethyl acetate which negatively affected the germination percentage.

Table 3. Germination percentage (G\%), germination velocity index (GVI) and average time of germination (AGT) of Solanum lycopersicum, Euphorbia heterophylla, Bidens pilosa and Glycine max submitted to the extracts of Crambe abyssinica, water distilled (negative control) e herbicide (positive control).

\begin{tabular}{|c|c|c|c|c|c|c|}
\hline \multirow{2}{*}{ Treatments } & \multicolumn{3}{|c|}{ S. lycopersicum } & \multicolumn{3}{|c|}{ E. heterophylla } \\
\hline & $\mathrm{G} \%{ }^{(1)}$ & $\mathrm{GVI}^{(1)}$ & $\mathrm{ATG}^{(1)}$ & $\mathrm{G} \%{ }^{(1)}$ & GVI $^{(1)}$ & $\mathrm{ATG}^{(1)}$ \\
\hline Water (-) & $92.00 \mathrm{~A}$ & $7.41 \mathrm{~A}$ & $3.35 \mathrm{~A}$ & $94.00 \mathrm{~A}$ & $14.77 \mathrm{~A}$ & $1.78 \mathrm{~A}$ \\
\hline Herbicide(+) & $34.00 \mathrm{a}$ & $1.36 \mathrm{a}$ & $6.67 \mathrm{a}$ & $44.00 \mathrm{a}$ & $3.52 \mathrm{a}$ & $3.21 \mathrm{a}$ \\
\hline Hexane & $10.00 \mathrm{~B} \mathrm{~b}$ & $0.33 \mathrm{~B} \mathrm{~b}$ & $7.69 \mathrm{~B} \mathrm{~b}$ & $97.00 \mathrm{~A} \mathrm{~b}$ & $11.64 \mathrm{~B} \mathrm{~b}$ & $2.17 \mathrm{~B} \mathrm{~b}$ \\
\hline Ethyl acetate & $0.00 \mathrm{~B} \mathrm{~b}$ & $0.00 \mathrm{~B} \mathrm{~b}$ & $0.00 \mathrm{~B} \mathrm{~b}$ & $96.00 \mathrm{~A} \mathrm{~b}$ & $11.58 \mathrm{~B} \mathrm{~b}$ & $2.12 \mathrm{~B} \mathrm{~b}$ \\
\hline Methanolic & $61.00 \mathrm{~B} \mathrm{~b}$ & $2.16 \mathrm{~B} \mathrm{~b}$ & $7.17 \mathrm{~B} \mathrm{a}$ & $92.00 \mathrm{~A} \mathrm{~b}$ & $11.25 \mathrm{~B} \mathrm{~b}$ & $2.08 \mathrm{~B} \mathrm{~b}$ \\
\hline p-value & $<0.001 *$ & $0.001 *$ & $<0.001 *$ & $<0.001 *$ & $<0.001 *$ & $<0.001^{*}$ \\
\hline \multirow[t]{3}{*}{$\mathrm{CV}(\%)$} & 11.35 & 12.46 & 5.83 & 6.43 & 10.15 & 5.72 \\
\hline & \multicolumn{3}{|l|}{ B. pilosa } & \multicolumn{3}{|l|}{ G. $\max$} \\
\hline & $\mathrm{G} \%{ }^{(1)}$ & GVI $^{(1)}$ & $\mathrm{ATG}^{(2)}$ & $\mathrm{G} \%{ }^{(1)}$ & $\mathrm{GVI}^{(1)}$ & ATG $^{(1)}$ \\
\hline Water (-) & $90.00 \mathrm{~A}$ & $7.00 \mathrm{~A}$ & $3.89 \mathrm{~A}$ & $93.00 \mathrm{~A}$ & $22.75 \mathrm{~A}$ & $2.07 \mathrm{~A}$ \\
\hline Herbicide(+) & $94.00 \mathrm{a}$ & $4.38 \mathrm{a}$ & $5.58 \mathrm{a}$ & $94.00 \mathrm{a}$ & $23.33 \mathrm{a}$ & $2.02 \mathrm{a}$ \\
\hline Hexane & $5.00 \mathrm{~B} \mathrm{~b}$ & $0.19 \mathrm{~B} \mathrm{~b}$ & $6.50 \mathrm{~B} \mathrm{~b}$ & $90.00 \mathrm{~A} \mathrm{a}$ & $20.17 \mathrm{~B} \mathrm{~b}$ & $2.36 \mathrm{~B} \mathrm{~b}$ \\
\hline Ethyl acetate & $6.00 \mathrm{~B} \mathrm{~b}$ & $0.25 \mathrm{~B} \mathrm{~b}$ & $6.75 \mathrm{~B} \mathrm{~b}$ & $93.50 \mathrm{~A} \mathrm{a}$ & $22.98 \mathrm{~A} \mathrm{a}$ & $2.06 \mathrm{~B} \mathrm{a}$ \\
\hline Methanolic & $90.00 \mathrm{~A} \mathrm{a}$ & $6.49 \mathrm{~A} \mathrm{~b}$ & $4.39 \mathrm{~A} \mathrm{~b}$ & $88.50 \mathrm{~A} \mathrm{~b}$ & $20.61 \mathrm{~B} \mathrm{~b}$ & $2.25 \mathrm{~B} \mathrm{~b}$ \\
\hline p-value & $<0.001 *$ & $<0.001^{*}$ & $0.003 *$ & $0.023^{*}$ & $<0.001^{*}$ & $<0.001^{*}$ \\
\hline $\mathrm{CV}(\%)$ & 8.25 & 9.76 & 14.88 & 2.67 & 3.02 & 2.32 \\
\hline
\end{tabular}

Notes: Different capital letters in the collun present significance between treatments and the negative control (water) and caseletters in the collum present significance between the treatments and the positive control (herbicide). ${ }^{1} \mathrm{~F}$ test (ANOVA) and Dunnett test (data met the statistical model assumptions: normality and homogeneity of variances). ${ }^{2}$ Kruskal-Wallis test and Wilcoxon (data did not meet the statistical model assumptions: heterogeneity of variances). *Significant (p-value $<0.05)$. CV\%: coefficient of variation

The results here presented suggest that the extracts of $C$. abyssinica have compounds with toxic effects, because they negatively interfere on the germination (Table 3) of the bioindicator $S$. lycopersicum, when compared to the negative control (water), at 5\% of significance. Such effects may have been caused by compounds found in the phytochemical screening (Table 2), because with the extraction methodology used in this work the compounds of intermediary polarity as terpenoids and flavonoids are present in the extracts. Phytotoxic substances belong mainly to these groups (KIM at al., 2005). They are considered germination inhibitors, and can block the preparation metabolism for the germination or prevent gas exchange, as well as they can inhibit the phytohormones activity and cell elongation (MARCOS FILHO, 2015).

Seeds of E. heterophylla submitted to hexane, ethyl acetate and methanolic extracts did not present significant difference on the germination percentage when compared to the negative control (water), at $5 \%$ of significance. However, a reduction in the GVI and an increase in the AGT occurred. Although, if compared with the positive control (herbicide), all the extracts differ statistically at 5\% of significance, in other words, did not reduce the germination percentage and GVI and increased the AGT. We can also notice that, even though the germination percentage reduced, the herbicide did not inhibit completely the weeds, presenting $44 \%$ of germination. 
Studies performed by Agostinetto and Vargas (2009) with E. heterophylla have indicated resistance to the acetolactate synthase-inhibiting herbicides (ALS), these resistant biotypes survived treatments with doses higher than ten times the recommended dose in field, and the growth rate and biomass production are similar among the resistant and sensible biotypes.

The germination of $B$. pilosa seeds submitted to hexane and ethyl acetate extracts presented accentuated reduction of GVI and G\% values, as well as increase in the AGT, when compared to the negative control (water). Considering the positive control (herbicide), we can observe that the hexane and ethyl acetate extracts also reduced the germination percentage and GVI, and increased the AGT, while the methanolic extract increased the GVI and reduced the AGT, in other words, it benefited the weed germination.

We can also notice that the positive control (herbicide) presented a high germination percentage of $B$. pilosa, this result indicates that the weed is resistant to such herbicide, as already described by Guerra et al. (2011), which tested the effect of different herbicides on this weed. Due resistance, alternatives are sought to control this weed, and the extracts studied in this work can be important in such way. As already verified in the phytochemical screening (Table 2), the ethyl acetate extract presented the flavonoid, which according to Marcos Filho (2015) is considered a germination inhibitor and can block the preparatory metabolism for germination or stop the gas exchanges. Thus, this compound can be isolated and tested as an alternative control of $B$. pilosa.

The relevance of testing the treatments effects on G. max was to discover if these extracts obtained from $C$. abyssinica can harm the crop development when applied in the weed control. Thereby, it can be noticed that the germination percentage of seeds did not differed statistically, at $5 \%$ of significance, when the treatments with the extracts were compared to the negative control (water), however there was GVI reduction when submitted to the hexane and methanolic extracts and AGT increase for all treatments. When the extracts were compared to the positive control (herbicide) we verified that the methanolic extract reduced the parameters related to germination.

An important indicator of allelopathy is the index of allelopathic effect answer ( $R I$ ) (Figure 2), which varies from -1 to +1 . Negative values indicate inhibitory effects and positive values indicate stimulant effects. According with this index the bioindicator species $S$. licopersicum was sensible to all extracts indicating inhibitory allelopathic effects of $C$. abyssinica compounds extracted through hexane, ethyl acetate and methanol solvents. This effect was inhibitory (presenting low or high intensity) for all the species and in all the extracts, with exception to soybean, on which the herbicide and the ethyl acetate extract promoted an effect slightly stimulant.

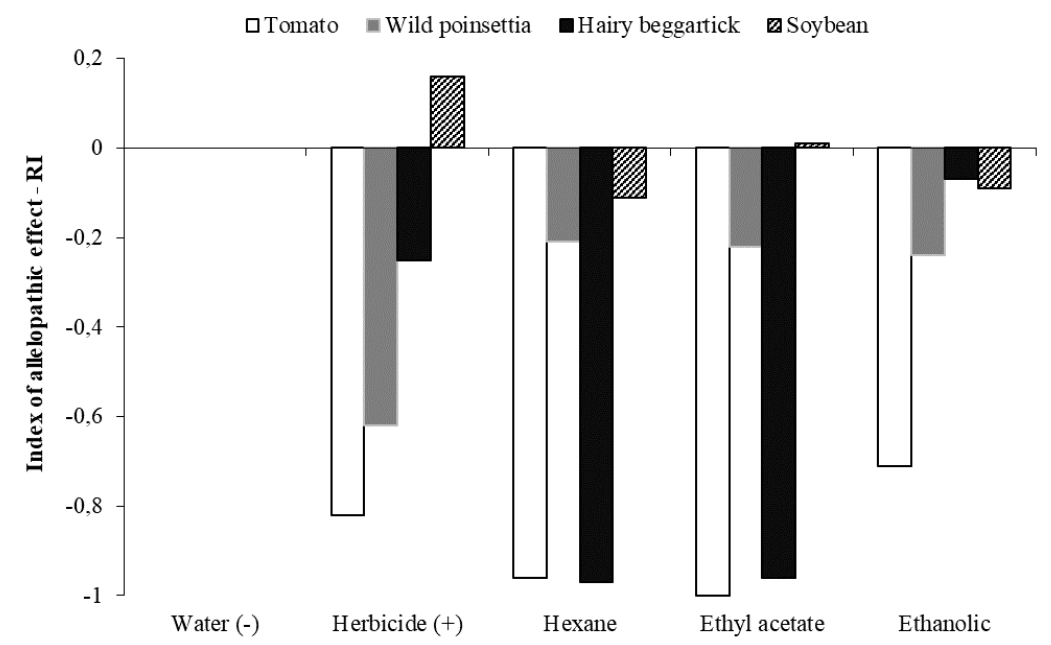

Figure 2 Index of allelopathic effect answer (RI) for Solanum licopersicum, Euphorbia heterophylla, Bidens pilosa and Glycine max submitted to comercial herbicide (atrazine) and 1\% extracts (hexane, ethyl acetate and methanolic) of Crambe abyssinica.

Particular attention is drawn to the effects of the hexane and ethyl acetate extracts on $S$. licopersicum (tomato) and B. pilosa (hairy beggartick), which was close to -1 , in other words, it was highly inhibitory. For B. pilosa, the hexane and ethyl acetate extracts presented a greater effect than 
the commercial herbicide. While the effect on E. heterophylla was slightly high only when the commercial herbicide was used, fact noticed also on seed germination and seedlings development (Table 3 and 4).

For G. $\max$ it was noticed a slight inhibitory effect of the hexane and methanolic extracts and, stimulant effects of the ethyl acetate and herbicide extracts. Thus, the extracts did not have a relevant negative effect on this species. These results indicate the possibility of using the isolation of bioactives compounds of crambe as a future bioherbicide, aiming to control mainly the weed $B$. pilosa without damages to the G. max crops.

The positive allelopathic effect caused by the ethyl acetate extract, on soybean, may be related to the presence of the compound flavonoid, verified in the phytochemical screening (Table 2), since according to Moreira and Siqueira (2006), the allelochemical effects vary depending on the substance concentration. There can be absence of effect in low concentrations or positive effect as the concentration arises.

However, in the study performed by Rizzardi et al. (2008) with the species canola, belonging to the family Brassicaceae, the authors observed an inhibitory effect of leaves, roots and stem of canola in the emergence velocity and in the germination percentage of soybean and hairy beggartick.

It is important that the new products available for weeds control present the same efficiency as the current synthetic products commercialized and, also, is substantial that they do not cause the environmental and health problems provoked by the synthetic ones (SOUZA FILHO; ALVES, 2002). Rizvi et al. (1980) and Jabran et al. (2015) mention that the pesticides originated from chemical substances produced by plants are more systemic, and they are more easily biodegraded than the synthetic pesticides.

\section{Extracts effects on seedlings grow}

The results regarding the seedling development of S. lycopersicum, E. heterophylla, $B$. pilosa and $G$. max submitted to $C$. abyssinica extracts, distilled water (negative control) and herbicide (positive control) are presented on Table 4.

Table 4. Shoot (S) and root (R) and dry matter (DM) of Solanum lycopersicum, Euphorbia heterophylla, Bidens pilosa and Glycine max submitted to Crambe abyssinica extracts, distilled water (negative control) and herbicide (positive control).

\begin{tabular}{|c|c|c|c|c|c|c|}
\hline \multirow{2}{*}{ Treatments } & \multicolumn{3}{|c|}{ S. lycopersicum } & \multicolumn{3}{|c|}{ E. heterophylla } \\
\hline & $\mathrm{S}(\mathrm{cm})^{(1)}$ & $\mathrm{R}(\mathrm{cm})^{(1)}$ & $\mathrm{DM}(\mathrm{mg})^{(2)}$ & $\mathrm{S}(\mathrm{cm})^{(1)}$ & $\mathrm{R}(\mathrm{cm})^{(1)}$ & $\mathrm{DM}(\mathrm{mg})^{(2)}$ \\
\hline Water (-) & $2.22 \mathrm{~A}$ & $6.66 \mathrm{~A}$ & $32.48 \mathrm{~A}$ & $4.14 \mathrm{~A}$ & $7.10 \mathrm{~A}$ & $147.25 \mathrm{~A}$ \\
\hline Herbicide(+) & $0.73 \mathrm{a}$ & $1.75 \mathrm{a}$ & $10.20 \mathrm{a}$ & $5.88 \mathrm{a}$ & $2.99 \mathrm{a}$ & $37.55 \mathrm{a}$ \\
\hline Hexane & $0.10 \mathrm{~B}$ a & $0.32 \mathrm{~B} \mathrm{~b}$ & $0.02 \mathrm{~B} \mathrm{~b}$ & $3.32 \mathrm{~A} \mathrm{~b}$ & $3.12 \mathrm{~B} \mathrm{a}$ & $147.73 \mathrm{~A} \mathrm{~b}$ \\
\hline Ethyl acetate & $0.00 \mathrm{~B} \mathrm{a}$ & $0.00 \mathrm{~B} \mathrm{~b}$ & $0.00 \mathrm{~B} \mathrm{~b}$ & $4.26 \mathrm{~A} \mathrm{~b}$ & $2.04 \mathrm{~B} \mathrm{a}$ & $69.78 \mathrm{~B} \mathrm{~b}$ \\
\hline Methanol & $1.78 \mathrm{~B} \mathrm{~b}$ & $2.43 \mathrm{~B} \mathrm{a}$ & $16.13 \mathrm{~B} \mathrm{~b}$ & $2.77 \mathrm{~B} \mathrm{~b}$ & $6.66 \mathrm{~A} \mathrm{~b}$ & $89.05 \mathrm{~B} \mathrm{~b}$ \\
\hline p-value & $0.002^{*}$ & $<0.001^{*}$ & $<0.001^{*}$ & $<0.001 *$ & $<0.001 *$ & $0.002^{*}$ \\
\hline \multirow[t]{3}{*}{$\mathrm{CV}(\%)$} & 53.99 & 26.8 & 12.91 & 11.66 & 18.74 & 8.27 \\
\hline & \multicolumn{3}{|l|}{ B. pilosa } & \multicolumn{3}{|l|}{ G. $\max$} \\
\hline & $\mathrm{S}(\mathrm{cm})^{(1)}$ & $\mathrm{R}(\mathrm{cm})^{(1)}$ & $\mathrm{DM}(\mathrm{mg})^{(1)}$ & $\mathrm{S}(\mathrm{cm})^{(1)}$ & $\mathrm{R}(\mathrm{cm})^{(1)}$ & $\mathrm{DM}(\mathrm{mg})^{(1)}$ \\
\hline Water (-) & $2.32 \mathrm{~A}$ & $3.42 \mathrm{~A}$ & $28.27 \mathrm{~A}$ & $9.27 \mathrm{~A}$ & $7.85 \mathrm{~A}$ & $470,83 \mathrm{~A}$ \\
\hline Herbicide(+) & $2.02 \mathrm{a}$ & $2.19 \mathrm{a}$ & $6.05 \mathrm{a}$ & $10.37 \mathrm{a}$ & $11.27 \mathrm{a}$ & $462,57 \mathrm{a}$ \\
\hline Hexane & $0.00 \mathrm{~B} \mathrm{~b}$ & $0.00 \mathrm{~B} \mathrm{~b}$ & $0.00 \mathrm{~B} \mathrm{~b}$ & $7.75 \mathrm{~B} \mathrm{~b}$ & $9.07 \mathrm{~A} \mathrm{~b}$ & $520,82 \mathrm{~B} \mathrm{~b}$ \\
\hline Ethyl acetate & $0.16 \mathrm{~B} \mathrm{~b}$ & $0.11 \mathrm{~B} \mathrm{~b}$ & $0.01 \mathrm{~B} \mathrm{~b}$ & $10.82 \mathrm{~B} \mathrm{a}$ & $12.12 \mathrm{~B} \mathrm{a}$ & $487,07 \mathrm{~A} \mathrm{a}$ \\
\hline Methanol & $3.10 \mathrm{~B} \mathrm{~b}$ & $2.90 \mathrm{~B} \mathrm{~b}$ & $21.68 \mathrm{~B} \mathrm{~b}$ & $8.97 \mathrm{~A} \mathrm{~b}$ & $8.47 \mathrm{~A} \mathrm{~b}$ & $472,05 \mathrm{~A}$ a \\
\hline p-value & $<0.001 *$ & $<0.001^{*}$ & $0.001 *$ & $<0.001^{*}$ & $<0.001^{*}$ & $0,008^{*}$ \\
\hline $\mathrm{CV}(\%)$ & 13.95 & 12.66 & 14.16 & 6.55 & 10,50 & 4,22 \\
\hline
\end{tabular}

Notes: Different capital letters in the collun present significance between treatments and the negative control (water) and caseletters in the collum present significance between the treatments and the positive control (herbicide). ${ }^{1} \mathrm{~F}$ test (ANOVA) and Dunnett test (data met the statistical model assumptions: normality and homogeneity of variances). ${ }^{2}$ Kruskal-Wallis test and Wilcoxon (data did not meet the statistical model assumptions: heterogeneity of variances). *Significant (p-value $<0.05)$. CV\%: coefficient of variation 
The parameters regarding the $S$. lycopersicum growth presented significant difference when the treatments were compared to the negative control (water), highlighting the reduction of shoots, roots and dry matter of plants exposed to the hexane, ethyl acetate and methanolic extracts. Also, when the extracts were compared to the positive control (herbicide), there was significant difference only for the methanolic extract, stimulating both shoot and dry matter. As well as in the germination (Table 3), the seedlings growth was inhibited with the hexane and ethyl acetate extracts when compared to the negative control (water) and positive control (herbicide), at $5 \%$ of significance.

Corroborating this results, Nunes et al (2014) have also verified that aqueous extracts of Crambe abyssinica and Raphanus sativus shoots, at the flowering period, interfered in the lettuce and cucumber (bioindicators) and did not presented negative effects on soybean seedlings.

The growth of $E$. heterophylla plants showed shoot and dry matter reduction when exposed to methanolic extract when compared to the negative control (water). Considering the positive control (herbicide) was verified that the hexane, ethyl acetate and methanolic extracts reduced the length of shoots and dry matter of the weed. Only the methanolic extract promoted increase in root length.

As well as verified for the bioindicator species S. lycopersicum, a stimulus was observed for the variable root length (Table 4), which can be due the presence of the compound saponin, identified in the extraction with the methanol solvent (Table 2), since it was the only different compound found. This fact may be due the direct and prolong contact of the roots with the extract (ALIYU; MUSTAPHA, 2014), and this may have caused the stimulation.

The same way Spiassi et al. (2015) aiming to find control alternatives, for the wild poinsettia, verified that the culture filtrate of Fusarium solani reduced the shoot length and fresh matter of the wild poinsettia, without negatively affect the soybean, it may be used as an alternative control of this weed, once in the present study there was no inhibition of this crop.

Is possible to verify the inhibitory effect in the $B$. pilosa seedlings growth exposed to the hexane and ethyl acetate extracts when compared to the negative control (water), at 5\% of significance, with exception to the methanolic extract which promoted shoot length increase. However, the hexane and ethyl acetate extracts effect were significant and reduced the shoot length, root and dry matter.

The growth reduction on tomato, wild poinsettia and hairy beggartick seedlings, may have happened due the interaction between allelochemicals and plant hormones, since studies point out that allelopathic compounds can inhibit gibberellins activity and the indoleacetic acid (IAA), preventing phases from the cycle and cell elongation, and consequently altering the seedling growth (HABERMANN et al., 2015).

When the treatments were compared to the positive control (herbicide) it can be observed that the three extracts (hexane, ethyl acetate and methanolic) differed from the control, while the hexane and ethyl acetate inhibited completely the growth parameters, which means, there was no seedlings development, the methanolic extract increased the shoot, root and dry matter length.

The hexane and ethyl acetate extracts tested in this work were efficient to inhibit the germination (Table 3) and growth of this weed, with a more accentuated effect than the commercial herbicide (Table 4). Corroborating with the results of Cruz et al. (2000) and Ferreira et al. (2007), which observed that the Eucalyptus citriodora extract reduced significantly the germination of $B$. pilosa seeds.

Due the undesirability $B$. pilosa on agricultural lands and the resistance of this weed to the herbicide used, this result is of great importance, because it demonstrates that is possible to obtain new and alternative control methods of this plant, aiming higher crop yields and decrease in the use of herbicide that contaminate the biological systems.

G. max seedlings showed shoot reduction, if compared to the negative (water) and positive (herbicide) control when submitted to hexane and methanolic extract, and increase when exposed to ethyl acetate extract. Considering the negative (water) and positive (herbicide) control, it can be observed that there was increase in the dry matter of seedlings submitted to the hexane extract.

The ethyl acetate extract did not interfere negatively on the germination (Table 3, Figure 1) and soybean growth (Table 4). Thereby, it can be used as a control to hairy beggartick without negatively interfering on the soybean crop, being then a control alternative of this weed.

The growth stimulus, as observed to G. $\max$ in this work, is described in studies regarding allelopathy and it is possible that this process be related to the influence of the extracts on the phytohormone production of the target species or increase in the tissues sensibility (RICE, 1984). According to Hong et al. (2004), the greater growth 
of seedling in low extract concentration may also be due a protection mechanism.

We indicate, so, the possibility of isolating the bioactive compounds of $C$. abyssinica for further use as an alternative control of the weed $B$. pilosa. We also recommend that more detailed studies be made to isolate and identify the active molecules of C. abyssinica extracts, in order to complement the results of this work.

\section{CONCLUSIONS}

The main groups of compounds identified in crambe $(C$. abyssinica) extracts were: saponins, pentacyclic triterpenoids, free steroids, flavonoids and tannins. There were no signs of coumarins, phenols nor alkaloids.
There is an inhibitory effect of the hexane, ethyl acetate and methanolic extracts of crambe on the bioindicator species tomato ( $S$. licopersicum). The ethyl acetate and hexane extracts also presented this effect on the weed hairy beggartick (B. pilosa), without negatively affecting the soybean ( $G$. max). On the wild poinsettia (E. heterophylla) the extracts did not present inhibitory effects.

\section{ACKNOWLEDGEMENTS}

The authors are grateful to CAPES for providing the doctoral scholarship of the first author, FAG for providing the agricultural area, and professor Luis Francisco Angeli Alves and Fabiana Gisele Pinto for allowing the use of the rotary evaporator at the Agricultural Biotechnology lab of UNIOESTE.

RESUMO: Este trabalho objetivou identificar grupos de compostos do metabolismo secundário de Crambe abyssinica e avaliar a bioatividade dos extratos hexânico, acetato etílico e metanólico $1 \%$ sobre a germinação de sementes e o crescimento de plântulas de tomate, leiteiro, picão-preto e soja. O screening fitoquímico considerou a presença ou ausência de saponinas totais, triterpenóides, esteroides, flavonoides, cumarinas, taninos, fenóis e alcaloides. Nas sementes avaliou-se a porcentagem de germinação, índice de velocidade de germinação, tempo médio de germinação, índice de resposta do efeito alelopático, comprimento de parte aérea e raiz e massa seca das plântulas. No screening fitoquímico observou-se que cada solvente extraiu compostos diferentes. Flavonóides foram encontrados somente no extrato acetato etílico e saponina apenas no extrato metanólico. Verificou-se elevado efeito alelopático dos extratos hexânico, acetato de etila e metanólico de crambe sobre a espécie bio-indicadora tomate. Os extratos hexânico e acetato etílico também apresentaram efeito inibitório sobre a planta invasora picão-preto e não tiveram efeitos negativos sobre a soja. Existe a possibilidade de isolamento de compostos bioativos de crambe para utilização como possível bioherbicida para controle alternativo da planta invasora picão-preto.

PALAVRAS-CHAVE: Bio-herbicida. Controle alternativo. Extratos de crambe. Picão-preto.

\section{REFERENCES}

AGOSTINETTO, D.; VARGAS, L. Resistência de plantas daninhas a herbicidas no Brasil. Passo Fundo: Bethier, 2009. 352p.

ALIYU, U. S. B. S.; MUSTAPHA, Y. Allelophatic effect of Calotropis procera on millet and sorghum. Unique Research Journal of Agricultural Sciences, USA, v. 2(4), p. 037-041, 2014.

ALVES, M. C. S.; MEDEIROS FILHO, S.; INNECO, R.; TORRES, S. B. Alelopatia de extratos voláteis na germinação de sementes e no comprimento da raiz de alface. Pesquisa Agropecuária Brasileira, Brasília, v. 39, p. 1083-1086, 2004. Disponível em: <http://www.scielo.br/pdf/pab/v39n11/22579.pdf>. Acesso em: 03 out. 2016. https://doi.org/10.1590/S0100-204X2004001100005 
BESSA, N. G. F.; BORGES, J. C. M.; BESERRA, F. P.; CARVALHO, R. H. A.; PEREIRA, M. A. B.; Fagundes, R.; ALVES, A. Prospecção fitoquímica preliminar de plantas nativas do cerrado de uso popular medicinal pela comunidade rural do assentamento vale verde Tocantins. Revista Brasileira de Plantas Medicinais, Botucatu, v. 15, n. 4, supl. 1, p. 692-707, 2013. Disponível em: $<$ http://www.scielo.br/scielo.php?script=sci_arttext\&pid=S1516-05722013000500010\&lng=en\&nrm=iso $>$. Acesso em: 03 out. 2016. https://doi.org/10.1590/S1516-05722013000500010

BORGES, E. B.; ALVES, C. C. F.; ALVES, J. M.; FERREIRA, N. L. Isolamento, purificação e caracterização de metabólitos especiais de nabo forrageiro (Raphanus sativus L.). In: I CONGRESSO DE PESQUISA E PÓS-GRADUAÇÃO DO CÂMPUS RIO VERDE DO IFGOIANO, 06 e 07 de novembro de 2012. Rio Verde. Anais. Rio Verde: IFGoiano, 2012. p. 1-3.

BRASIL. Ministério da agricultura, Pecuária e Abastecimento. Regras para análise de sementes. Brasília, Mapa/ACS, 2009. 399 p.

CANNAS, A. Tannins: fascinating but sometimes dangerous molecules. Disponível em:

$<$ http://poisonousplants.ansci.cornell.edu/toxicagents/tannin.html/>. Acesso em: 21 de out. 2015.

CONCENÇO, G.; SILVA, C. J.; STAUT, L. A.; PONTES, C. S.; LAURINDO, L. C. A. S.; SOUZA, N. C. D. S. Weeds occurrence in areas submitted to distinct winter crops. Planta Daninha, Viçosa, v. 30, n. 4, p. $747-$ 755, 2012. https://doi.org/10.1590/S0100-83582012000400008

CORREIA, N. M. SOUZA, I. F.; KLINK, U. P. Palha de sorgo associada ao herbicida imazamox no controle de plantas daninhas na cultura da soja em sucessão. Planta Daninha, Viçosa, v.23, n. 3, 2005. Disponível em: <http://www.scielo.br/scielo.php?pid=S0100-83582005000300012\&script=sci_abstract\&tlng=pt $>$. Acesso em: 05 set. 2016. https://doi.org/10.1590/S0100-83582005000300012

CRUZ, M. E. S.; NOZAKI, M. H.; BATISTA, M. A. Plantas medicinais. Biotecnologia Ciência e Desenvolvimento, Brasília, v. 15, p. 28-34, 2000.

DUKE, S. O.; ROMAGNI. J. G.; DAYAN, F. E. Natural products as sources for new mechanisms of herbicidal action. Crop Protection, Oxford, v. 19, n. 8, p. 583-589, 2000. Disponível em: <https://www.sciencedirect.com/science/article/pii/S0261219400000764>. Acesso em: 12 set. 2016. https://doi.org/10.1016/S0261-2194(00)00076-4

DURAM, J. M.; TORTOSA, M. E. The effect of mechanical and chemical scarification on germination of charlock (Sinapsis arvensis L.) seeds. Seed Science Technology, Zürich, v. 13, n. 1, p. 155-163, 1985.

EDMOND, J. B.; DRAPALLA, W. J. The effects of temperature, sana and soil, and acetone on germination of okra seed. Proceedings of the American Society for Horticuticultural Science. Alexandria, v. 71, n. 2, p. 428-443, 1958.

EINHELLIG, F. A. Mechanisms and modes of actions of allelochemicals. In: PUTNAM, A. R.; TANG, C. S. (Eds.). The science of allelopathy. New York: John Willey \& Sons, 1986. p.171- 188.

EMPRESA BRASILEIRA DE PESQUISA AGROPECUÁRIA - EMBRAPA. Centro Nacional de Pesquisa de Solos. Sistema brasileiro de classificação de solos. 3 ed. Brasília, 2013. 253 p.

EVENARI, M. Germination inhibitors. Botanical Review, v. 15, p. 153-194, 1984.

https://doi.org/10.1007/BF02861721

FAGAN, E. B.; ONO, E. O.; RODRIGUES, J. D.; CHALFUN JÚNIOR, A.; NETO, D. D. Fisiologia vegetal: reguladores vegetais. Piracicaba, Editora Andrei, 2015. 
FALASCA. S. L.; LAMAS, M. C.; CARBALLO, S. M.; ANSCHAU, A. Crambe abyssinica: Na almost unknown crop with a promissory future to produced biodiesel in Argentina. International Journal of Hydrogen Energy, v. 35, p. 5808-5812, 2010. Disponível em: <https://www.sciencedirect.com/science/article/pii/S0360319910003952>. Acesso em: 12 set. 2016. https://doi.org/10.1016/j.ijhydene.2010.02.095

FERREIRA, M. C.; SOUZA, J. R. P.; FARIA, T. J. Potenciação alelopática de extratos vegetais na germinação e no crescimento inicial de B. pilosa e L. sativa. Ciência Agrotecnica, v. 31, n. 4, p. 1054-60, 2007. https://doi.org/10.1590/S1413-70542007000400017

GAO, X.; LI, M. E. I.; GAO, Z.; LI, C.; Sun, Z. Allelopathic effects of Hemistepta lyrata on the germination and growth of wheat, sorghum, cucumber, rape, and radish seeds. Weed biology and management, Japan, v. 9, n. 3, p. 243-249, 2009. https://doi.org/10.1111/j.1445-6664.2009.00345.x

GRISI, P.; GUALTIERI, S.; RANAL, M.; SANTANA, D. Efeito alelopático do fruto de Sapindus saponaria na germinação e na morfologia de plântulas daninhas e de hortaliças. Planta Daninha, Viçosa, v. 29, n. 2, p. 311-322, 2011. Disponível em:

<http://www.scielo.br/scielo.php?script=sci_arttext\&pid=S010083582011000200009\&lng=en\&nrm=iso $>$. Acesso em: 04 Sept. 2016. https://doi.org/10.1590/S0100-83582011000200009

GUERRA, N.; OLIVEIRA JÚNIOR, R. S.; CONSTANTIN, J.; OLIVEIRA NETO, A. M.; ALMEIDA DAN, H.; ALONSO, D. G.; CAMPOS JUMES, T. M. Efeito da modalidade de aplicação sobre o controle de Bidens pilosa resistente a herbicidas inibidores da enzima ALS. Global Science and Technology, v. 4, n. 1, 2011.

HABERMANN, E.; IMATOMI, M.; PEREIRA, C. V; PONTES, F. C.; GUALTIERI, J. Actividad fitotóxica de las cortezas del tallo y hojas de Blepharocalyx salicifolius (Myrtaceae) sobre especies invasoras. Acta

Biológica Colombiana. Bogotá, v. 20, n. 1, p.153-162, 2015.

HARRIS, H. B.; BURNS, R. E. Influence of tannin content on preharvest seed germination in sorghum. Agronomy Journal, v.62. p. 835-836, 1970. https://doi.org/10.2134/agronj1970.00021962006200060051x

HONG, N. H.; XUAN, T. D.; EIJI, T.; KHANH, T. D. Paddy weed control by higher plants from Southeast Asia. Crop Protection. v. 23, n.3, p.255-261, 2004. https://doi.org/10.1016/j.cropro.2003.08.008

JABRAN, K.; MAHAJAN, G.; SARDANA, V.; CHAUHAN, B. S. Allelopathy for weed control in agricultural systems. Crop Protection, v. 72, p. 57-65, 2015. https://doi.org/10.1016/j.cropro.2015.03.004

JUNTILA, O. Seed and embryo germination in S. vulgaris and S reflexa as affected by temperature during seed development. Physiology Plantarum, Copenhagem, v. 29, n.2, p. 264-268, 1976.

https://doi.org/10.1111/j.1399-3054.1973.tb03103.x

KATOH, T.; KASUYA, M.; KAGAMIMORI, S.; KOZUKA, H. KAWANO, S. Effects of air-pollution on tannin biosynthesis and predation damage in cryptomeriajaponica. Phytochemistry, v. 28, n. 2, p. 439-445, 1989. https://doi.org/10.1016/0031-9422(89)80028-7

KIM, Y. O.; JOHNSON, J. D.; LEE, E. J. Phytotoxic effects and chemical analysis of leaf extracts from three Phytolaccaceae species in South Korea. Journal of Chemical Ecology, v. 31, n. 5, 2005. https://doi.org/10.1007/s10886-005-4255-z

KOPPEN, W. Climatologia: con un estudio de los climas de la tierra. Fondo de Cultura Econômica. México, 1948, 479p.

LABOURIAU, L. G. A germinação das sementes. Washington: Secretaria-Geral da OEA, 1983. 174p. 
MACEDO JUNIOR, F. C. Espectroscopia de Ressonância Magnética Nuclear de 13 C no estudo de rotas biossintéticas de produtos naturais. Química Nova, São Paulo, v. 30, n. 1, p. 116-124, 2007. https://doi.org/10.1590/S0100-40422007000100023

MAGUIRE, J. D. Seeds of germination-aid selection and evaluation seedling emergence and vigor. Crop Science, Madison, v. 2, n. 1, p. 176-177, 1962. https://doi.org/10.2135/cropsci1962.0011183X000200020033x

MARCOS FILHO, J. Fisiologia de sementes de plantas cultivadas. Piracicaba: FEALQ, 2005. 495p.

MATOS, F. J. A., Introdução à fitoquímica experimental. Fortaleza: Edições UFC, 150 p. 2009.

MORELAND, D. E.; NOVITZKY, W. P. Effects of phenolic acids, coumarins and flavonoids on isolated and mitochondria. In: WALLER, G. R. (ED.). Allelochemicals: role in agriculture and forestry. Washington: American Chemical Society, 1987. https://doi.org/10.1021/bk-1987-0330.ch023

MOREIRA F. M. S.; SIQUEIRA, J. O. Microbiologia e bioquímica do solo. Lavras: Editora UFLA, 2006. 729 p.

NAKAGAWA, J. Testes de vigor baseados no desempenho das plântulas. In: KRZYZANOWSKI, F.C.; VIEIRA, R.D.; FRANCA NETO, J. B. F. Vigor de sementes: conceitos e testes. Londrina: ABRATES, 1999, $246 \mathrm{p}$.

NUNES, J. V. D.; MELO, D.; NÓBREGA, L. H. P.; LOURES, N. T. P.; SOSA, D. E. F. Atividade alelopática de extratos de plantas de cobertura sobre soja, pepino e alface. Revista Caatinga, Moçoró, v. 27, n. 1, p. $122-$ 130, 2014. Disponível em: <https://periodicos.ufersa.edu.br/index.php/caatinga/article/view/2990>. Acesso em: 04 Sept. 2016.

ONYILAGHA, J.; BALA, A.; HALLETT, R.; GRUBER, M.; SOROKA, J.; WESTCOTT, N. Leaf flavonoids of the cruciferous species, Camelina sativa, Crambe spp., Thlaspi arvense and several other genera of the family Brassicaceae. Biochemical Systematics and Ecology, v. 31, n. 11, p. 1309-1322, 2003. Disponível em: $<\mathrm{http}: / /$ www.sciencedirect.com/science/article/pii/S0305197803000747>. Acesso em 03 sept 2018. https://doi.org/10.1016/S0305-1978(03)00074-7

PARACAMPO, N. E. N. P. Prospecção fitoquímica de plantas medicinais. Belém: Embrapa Amazônia Oriental, 2011.

PITOL, C; BROCH, D. L; ROSCOE. R. Tecnologia e produção: Crambe 2010. Maracaju: Fundação MS, 2010. 60p.

R DEVELOPMENT CORE TEAM. R: A language and environment for statistical computing. R Foundation for Statistical Computing. Vienna, Austria, ISBN 3-900051-07-0. Avaliable at http://www.R-project.org (accessed Jun 2015).

RAVEN, P. H.; EVERT, R. F.; EICHHORN, S. E. Biologia Vegetal, $8^{\circ}$ ed. Rio de Janeiro: Guanabara Koogan, 2014, 906 p.

RICE, E. L. Allelopathy. 2 ed., New York: Academic press, 1984. 353 p.

RICE, E. L. PANCHOLY, S. K. Inhibition of nitrification by climax ecosystems. II. Additional evidence and possible role of tannins. American Journal of Botany, v. 60, p691-702, 1973. https://doi.org/10.1002/j.15372197.1973.tb05975.x

RICE, E. L. Some roles of allelopathic compounds in plant communities. Biochemical systematics and ecology, England, v. 5, p. 201-206 1977. https://doi.org/10.1016/0305-1978(77)90005-9 
RIPARDO FILHO, H. D. S.; PACHECO, L. C.; SOUZA FILHO, A. P. D. S.; GUILHON, G. M. S. P.; ARRUDA, M. S. P.; SANTOS, L. D. S. Bioensaios de atividade alelopática dos esteroides espinasterol, espinasterona e glicopiranosil espinasterol. Planta Daninha, Viçosa, v. 30, n. 4, p. 705-712, 2012. Disponível em: < http://www.scielo.br/pdf/pd/v30n4/03.pdf > . Acesso em: 04 Sept. 2014. https://doi.org/10.1590/S010083582012000400003

RIZVI, S. J. H.; MUKERJI, D.; MATHEUS, S. N. A new report on a possible source of natural herbicide. Indian Journal Experimental Biology, v 18, p.777-778, 1980.

RIZZARDI, M. A.; NEVES, R; LAMB, T. D; JOHANN; L. B. Potencial alelopático da cultura da canola (Brassica napus L. var. oleifera) na supressão de picão-preto (Bidens sp.) e soja. Revista Brasileira de Agrociência, Pelotas, v. 14, n. 2, p. 239-248, 2008.

SALISBURY, F. B; ROSS, C. W. Fisiologia das plantas. 4 ed. São Paulo: Cengage Learing, 2012, 774 p. SISTEMA METEOROLÓGICO DO PARANÁ - SIMEPAR. Dados recebidos para fins de pesquisa científica. Coletados na estação meteorológica de Cascavel - PR de maio a julho de 2014. Received in: 11/13/ 2015.

SOUZA FILHO, A. P. S.; ALVES, S. M. Alelopatia: princípios básicos e aspectos gerais. Belem: Embrapa Amazônia Oriental, 2002. 260p.

SOUZA FILHO, A. P. S.; GUILHON, G. M. S. P.; SANTOS, L. S. Metodologias empregadas em estudos de avaliação da atividade alelopática em condições de laboratório: revisão crítica. Planta Daninha, Viçosa, v. 28, n. 3, p. 698-697, 2010. https://doi.org/10.1590/S0100-83582010000300026

SOUZA FILHO, A. P. S.; PEREIRA, A. A. G.; BAYMA, J. C. Aleloquímico produzido pela gramínea forrageira Brachiaria humidicola. Planta Daninha, Viçosa, v. 23, n. 1, p. 25-32, 2005. Disponível em: $<$ http://www.scielo.br/scielo.php?script=sci_arttext\&pid=S0100-83582005000100004\&lng=en\&nrm=iso $>$. Acesso em: 06 Sept. 2017. http://dx.doi.org/10.1590/S0100-83582005000100004.

SPIASSI, A.; NÓBREGA, L. H. P; ROSA, D. M.; PACHECO, F. P.; SENEM, J.; PICCOLO DE LIMA, G. Allelopathic effects of pathogenic fungi on weed plants of soybean and corn crops. Bioscience Journal, Uberlândia, v. 31, n. 4, p. 1037-1048, 2015. Disponível em:

<http://www.seer.ufu.br/index.php/biosciencejournal/article/view/26142/16722>. Acesso em: 04 Sept. 2016. https://doi.org/10.14393/BJ-v31n4a2015-26142

TAIZ, L.; ZEIGER, E. Fisiologia vegetal. Artmed, 5a ed, Porto Alegre, 2013, 918 p.

TAKECHI, M.; ANAKA, Y.; TAKEHARA, M.; NONAKA, G. I.; NISHIOKA, I. Structure and antiherpetic activity among the tannins. Phytochemistry, v. 24, n. 10, p. 2245-2250, 1985. https://doi.org/10.1016/S00319422(00)83018-6

TEMMINK, J. H. M.; FIELD, J. A.; HAASTRECHT J. C.; MERKELBACH, R. C. M. Acute and sub-acute toxicity of bark tannins in carp (Cyprinus carpio L.). Water Research, v. 23, n. 3, p. 341-344, 1989. https://doi.org/10.1016/0043-1354(89)90100-0

WEIH, M.; DIDON, U. M. E.; RONNBERG WASTLJUNG A. C.; BJORKMAN C. Integrated agricultural research and crop breeding: Allelopathic weed control in cereals and long-term productivity in perennial biomass crops. Agricultural Systems. Wageningen, v. 97, n. 3, p. 99-107, 2008.

https://doi.org/10.1016/j.agsy.2008.02.009.

ZUANAZZI, J. A. S.; MONTANHA, J. A. Flavonoides. Cap 23. In: SIMÕES, C. M. O.; SCHENKEL, E. P.; GOSMAN, G.; MELLO, J. C. P.; MENTZ, L. A.; PETROVICK, P. R. Farmacognosia: da planta ao medicamento. Porto Alegre/Florianópolis: Editora da UFRGS/Editora da UFSC, 2003, 1102 p. 